\title{
DNA Relatedness of Bacillus brevis Migula 1900 Strains and Proposal of Bacillus agri sp. nov., nom. rev., and Bacillus centrosporus sp. nov., nom. rev.
}

\author{
L. K. NAKAMURA \\ Microbial Properties Research, National Center for Agricultural Utilization Research, Agricultural Research \\ Service, U.S. Department of Agriculture, Peoria, Illinois 61604
}

\begin{abstract}
Studies were carried out to determine the underlying reasons for the phenotypic heterogeneity of Bacillus brevis Migula 1900. DNA reassociation measurements demonstrated that 31 of 37 strains segregated into seven groups of genetically related organisms. The members of the seven groups were not related genetically to selected presently recognized Bacillus species that are strictly aerobic and form oval spores. The results of the DNA relatedness studies and phenotypic comparisons suggested that two of these groups have not been described previously and that the five other groups probably represent previously, but inadequately, described species. Two of the five groups are proposed as new species and are given the revived names Bacillus agri and Bacillus centrosporus. Thus, the phenotypic heterogeneity of $B$. brevis sensu lato results from the inclusion of genetically unrelated organisms in the taxon and not from the inherent variability of genetically related strains.
\end{abstract}

Bacillus brevis, a strictly aerobic species, was first described by Migula in 1900 (8). The discovery of gramicidin production heightened interest in this species and fostered the isolation of numerous strains, many of which varied significantly from the standard strains. Eventually, the heterogeneity among the strains engendered controversy concerning the definition of the species. For example, the gramicidin-producing isolates of Gause and Brazhnikova (5) grew optimally at $60^{\circ} \mathrm{C}$ but were considered not to be different from the mesophilic strains of Dubos and Hotchkiss (2); thus, a precedent was established for including thermophiles in the species $B$. brevis. Other unusual traits ascribed to strains of $B$. brevis are molluscicidal activity (14) and hyperproduction of proteins (18).

The wide discrepancies in growth temperatures, the occurrence of unusual characteristics in selected strains, and the wide range of $\mathrm{G}+\mathrm{C}$ values (47 to $55 \mathrm{~mol} \%$ [18]) suggested that $B$. brevis is a phenotypically heterogeneous species, an observation in keeping with the results of the numerical taxonomic comparisons of Priest et al. (12). Furthermore, in a previous study, only 25 of 87 strictly aerobic strains tentatively classified as $B$. brevis were found to exhibit high levels of DNA relatedness to the type strain of this taxon (10). The present study was undertaken to determine by using DNA reassociation measurements the taxonomic relationships of the strains misclassified as $B$. brevis. The findings of this study suggest that at least seven genetically unrelated species have been erroneously classified as $B$. brevis.

\section{MATERIALS AND METHODS}

Bacterial strains. The $B$. brevis strains used in this study are listed in Table 1 . Also included were strains NRRL NRS-663, NRRL NRS-1347, NRRL NRS-1351, and NRRL B-1172, the type strains of Bacillus badius Batchelor 1919, Bacillus alginolyticus Nakamura 1987, Bacillus chondroitinus Nakamura 1987, and Bacillus stearothermophilus Donk 1920, respectively. These strains are maintained in the Agricultural Research Service Culture Collection at the National Center for Agricultural Utilization Research. Each NRRL designation includes the prefix B-, which identifies strains that were obtained directly from individuals or strains that were isolated at the National Center for Agricultural Utilization Research, or the prefix NRS-, which identifies strains obtained from the Bacillus collection of N. R. Smith. All of the strains bearing the NRS- prefix were deposited in the Agricultural Research Service Culture Collection by R. E. Gordon.

Working stocks were cultured at $30^{\circ} \mathrm{C}$ on soil extract agar (6) until sporulation occurred and were stored at $4^{\circ} \mathrm{C}$.

Characterization. Strain characterization was carried out as described previously (10).

DNA isolation, $\mathbf{G}+\mathbf{C}$ contents, and DNA reassociation. The procedures used for DNA isolation and purification by hydroxylapatite chromatography and for estimating DNA reassociation values spectrophotometrically have been described previously (11). Reassociation values were calculated by the equation of De Ley et al. (1).

$\mathrm{G}+\mathrm{C}$ contents of the DNAs were estimated from their buoyant densities as determined by $\mathrm{CsCl}$ density gradient centrifugation in a model E ultracentrifuge (Beckman Instruments, Inc., Fullerton, Calif.) (13). Micrococcus luteus (synonym, "Micrococcus lysodeikticus") DNA with a buoyant density of $1.724 \mathrm{~g} / \mathrm{cm}^{3}$ (17) was purchased from Sigma Chemical Co., St. Louis, Mo., and was used as an internal standard.

Numerical analyses. Clustering for DNA relatedness was based on the unweighted-pair-group arithmetic average algorithm (16). The TAXAN program of David Swartz, University of Maryland, College Park, was used to carry out the analyses with a DTK PC-AT personal computer.

\section{RESULTS}

The 37 strains examined in this study were strains with $\mathrm{G}+\mathrm{C}$ contents of 45 to $54 \mathrm{~mol} \%$ that previously (10) had been shown to be distantly related genetically to $B$. brevis sensu stricto. DNA reassociation determinations performed with all 37 strains (i.e., each strain was compared with all of the other strains) established that 31 of the strains identified as $B$. brevis could be separated into seven distinct DNA relatedness groups (Fig. 1). Relegated to an eighth group were six strains (strains NRRL NRS-751, NRRL NRS-761, NRRL NRS-779, NRRL NRS-857, NRRL NRS-1222, and NRRL NRS-1366) 
TABLE 1. B. brevis strains compared in this study ${ }^{a}$

\begin{tabular}{|c|c|c|c|c|}
\hline Strain & $\begin{array}{l}\text { Received as } \\
\text { strain: }\end{array}$ & Source $^{b}$ & $\begin{array}{l}\mathrm{G}+\mathrm{C} \\
\text { content } \\
\text { (mol\%) }\end{array}$ & History \\
\hline \multicolumn{5}{|l|}{ Group 1} \\
\hline NRRL B-1157 & & 1 & 54 & H. R. Curran strain Penn-O, from A. Bondi, clinical isolate \\
\hline NRRL B-1158 & & 1 & 53 & H. R. Curran strain Penn-S, from A. Bondi, clinical isolate \\
\hline NRRL NRS-641 & NRS-641 & 2 & 52 & J. R. Porter, "B. ventricosus," from G. Bredemann \\
\hline NRRL NRS-873 & NRS-873 & 2 & 53 & J. R. Porter, "B. hollandicus" H1, from G. Bredemann \\
\hline NRRL NRS-874 & NRS-874 & 2 & 54 & J. R. Porter, " $B$. hollandicus" H2, from G. Bredemann \\
\hline NRRL NRS-1002 & NRS-1002 & 2 & 54 & J. R. Porter, “B. ventricosus,” from G. Bredemann \\
\hline NRRL NRS-1028 & NRS-1028 & 2 & 53 & A. Bondi strain Schotte \\
\hline NRRL NRS-1060 & NRS-1060 & 2 & 55 & C. T. Townsend and T. L. Zuck strain A \\
\hline NRRL NRS-1219 & NRS-1219 & 2 & 53 & C. Lamanna, "B. agri"” 13 \\
\hline NRRL NRS-1373 & NRS-1373 & 2 & 52 & W. G. Walter strain 141 \\
\hline \multicolumn{5}{|l|}{ Group 2} \\
\hline NRRL NRS-376 & NRS-376 & 2 & 49 & N. R. Smith, from soil \\
\hline NRRL NRS-378 & NRS-378 & 2 & 49 & N. R. Smith, from soil \\
\hline NRRL NRS-379 & NRS-379 & 2 & 49 & N. R. Smith, from soil \\
\hline NRRL NRS-380 & NRS-380 & 2 & 50 & N. R. Smith, from soil \\
\hline \multicolumn{5}{|l|}{ Group 3} \\
\hline NRRL NRS-135 & NRS-135 & 2 & 51 & W. C. Bohrer strain NCA $11773-2$, from spinach \\
\hline NRRL NRS-136 & NRS-136 & 2 & 50 & W. C. Bohrer strain NCA $11773-8$, from spinach \\
\hline NRRL NRS- 628 & NRS-628 & 2 & 51 & J. R. Porter, "B. pallidus," from G. Bredemann \\
\hline NRRL NRS-631 & NRS-632 & 2 & 50 & J. R. Porter, “B. rarus,” from G. Bredemann \\
\hline NRRL NRS-664 & NRS-664 & 2 & 49 & B. S. Henry strain 120 , "B. centrosporus" \\
\hline NRRL NRS-925 & NRS-925 & 2 & 51 & J. R. Porter, "B. pallidus" P2, from G. Bredemann \\
\hline \multicolumn{5}{|r|}{ 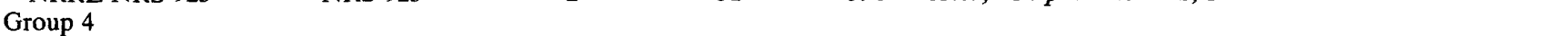 } \\
\hline NRRL B-541 & WRRL 550 & 3 & 48 & R. J. Dubos \\
\hline NRRL NRS-780 & NRS-780 & 2 & 51 & R. J. Dubos strain TC, from Turkish cheese \\
\hline NRRL NRS- 815 & NRS-815 & 2 & 53 & J. R. Porter, "B. bellus" B1, from G. Bredemann \\
\hline \multicolumn{5}{|r|}{ 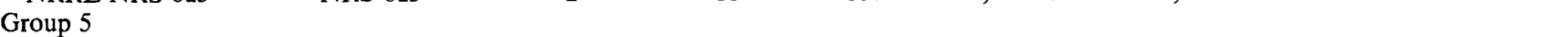 } \\
\hline NRRL NRS-1206 & NRS-1206 & 2 & 53 & H. W. Heuszer Army strain 39 \\
\hline NRRL NRS-1207 & NRS-1207 & 2 & 53 & H. W. Heuszer Army strain 723 \\
\hline NRRL NRS-1208 & NRS-1208 & 2 & 48 & H. W. Heuszer Army strain 842 \\
\hline \multicolumn{5}{|l|}{ Group 6} \\
\hline NRRL NRS-863 & NRS-863 & 2 & 45 & J. R. Porter, "B. formosus" F12, from G. Bredemann \\
\hline NRRL NRS-948 & NRS-948 & 2 & 50 & J. R. Porter, “B. rufescens" R8, from G. Bredemann \\
\hline NRRL NRS-1210 & NRS-1210 & 2 & 47 & H. W. Heuszer Army strain 1035 \\
\hline \multicolumn{5}{|r|}{ (2) } \\
\hline NRRL NRS-818 & NRS-818 & 2 & 52 & J. R. Porter, "B. borstelensis"' \\
\hline NRRL NRS-1029b & NRS-1029b & 2 & 54 & G. M. Eisenberg, "Bacillus schuylkilliensis" \\
\hline \multicolumn{5}{|l|}{ Group 8} \\
\hline NRRL NRS-751 & NRS-751 & 2 & 53 & R. J. Dubos gramicidin strain, from soil $(=\text { ATCC } 8185)^{c}$ \\
\hline NRRL NRS-761 & NRS-761 & 2 & 49 & L. T. Leonard, from soil \\
\hline NRRL NRS-779 & NRS-779 & 2 & 48 & R. J. Dubos strain oka, from oka cheese (= ATCC 8186) \\
\hline NRRL NRS -857 & NRS-857 & 2 & 50 & J. R. Porter, Bacillus firmus d-Utliberg F6, from G. Bredemann \\
\hline NRRL NRS- 1222 & NRS-1222 & 2 & 50 & D. H. Rose, from an orange \\
\hline NRRL NRS-1366 & NRS-1366 & 2 & 49 & R. Y. Stanier strain 13 \\
\hline
\end{tabular}

a Names in quotation marks are not on the Approved Lists of Bacterial Names (15) and have not been validly published since 1 January 1980.

b 1 , N. R. Smith collection maintained by R. E. Gordon, Rutgers University, New Brunswick, N.J.; 2, N. R. Smith, Agricultural Research Center, Beltsville, Md.; 3, Western Regional Research Center, Albany, Calif.

$c$ Designations in parentheses are equivalent strain designations.

that were distantly related to each other and to the other groups. The $\mathrm{G}+\mathrm{C}$ contents of the members of groups 1 through 7 were 52 to 55,49 to 50,49 to 51,48 to 53,48 to 53 , 45 to 50 , and 52 to 54 mol\%, respectively. The $\mathrm{G}+\mathrm{C}$ contents of the six unrelated strains ranged from 48 to $53 \mathrm{~mol} \%$.

Previously recognized strictly aerobic species that have $\mathrm{G}+\mathrm{C}$ contents of 44 to $52 \mathrm{~mol} \%$ and produce oval spores include $B$. badius, $B$. chondroitinus, $B$. alginolyticus, and $B$. stearothermophilus. DNA complementarity values of $30 \%$ or less were measured between the reference strains of the groups and the type strains of the previously recognized species (Table 2).

The phenotypic characteristics of the seven relatedness groups and $B$. brevis sensu stricto are shown in Table 3 . In general, whereas $B$. brevis sensu lato exhibited pronounced phenotypic heterogeneity, each of the groups was highly homogeneous. In contrast, the six unrelated strains formed a phenotypically heterogeneous group. The members of all of the groups were strictly aerobic, produced oval spores in swollen sporangia, were catalase positive, and produced negative responses in tests for growth at $50^{\circ} \mathrm{C}$, starch hydrolysis, acetylmethylcarbinol synthesis, urease activity, egg yolk lecithin decomposition, hydrogen sulfide production, indole production, propionate utilization, and fermentation of arabinose, lactose, melibiose, salicin, sorbitol, and xylose.

\section{DISCUSSION}

A previous study of 87 strains identified as $B$. brevis revealed that 80 of these strains had $G+C$ contents of 45 to 


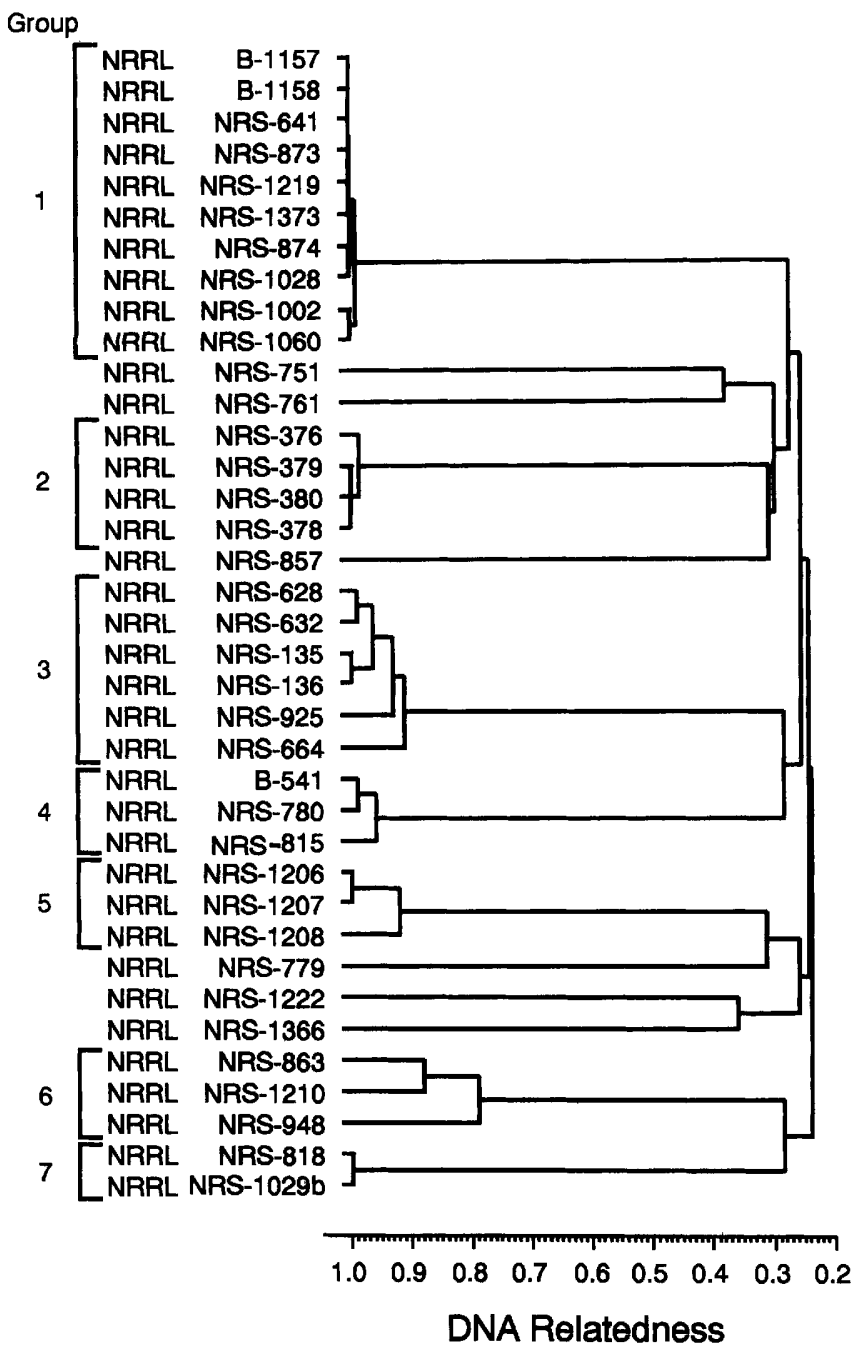

FIG. 1. Dendrogram showing the levels of DNA relatedness among the $B$. brevis strains studied, determined by using the simple matching coefficient and the unweighted-pair-group arithmetic average algorithm.

$56 \mathrm{~mol} \%$, a range that included the $\mathrm{G}+\mathrm{C}$ content $(49 \mathrm{~mol} \%)$ of the type strain (10). Seven strains had $\mathrm{G}+\mathrm{C}$ values of 41 mol\% or less; these strains were probably not $B$. brevis strains. Only 24 of the 80 organisms with $\mathrm{G}+\mathrm{C}$ contents of 45 to $56 \mathrm{~mol} \%$ formed a tight genetic cluster with the type strain (10) and thus could be considered members of the species sensu stricto. In this study 37 of the remaining 55 strains were examined to determine their taxonomic relationships.

On the basis of DNA reassociation data, seven distinct groups of genetically related organisms were identified among the 37 strains formerly identified as B. brevis. According to the data in Table 3 , each of the groups tends to be phenotypically homogeneous and can be readily distinguished from the other groups, as well as from B. brevis. These data established that the seven groups are genetically and phenotypically distinct entities.

The range of $\mathrm{G}+\mathrm{C}$ contents $(45$ to $56 \mathrm{~mol} \%$ ) for the seven DNA relatedness groups encompasses the range of DNA base contents for previously described strictly aerobic, oval-spored species, including $B$. alginolyticus Nakamura 1987, B. chondroitinus Nakamura 1987, and B. stearothermophilus Donk 1920. An additional species that can be considered is $B$. badius, whose members have $\mathrm{G}+\mathrm{C}$ contents of 44 to $47 \mathrm{~mol} \%$, a range of values just outside the range exhibited by the seven relatedness groups. Low DNA relatedness values $(30 \%$ or less) (Table 2 ) indicate that none of the seven groups is related to the four previously described species mentioned above.

Phenotypically, the inability of the members of all seven groups to grow at $50^{\circ} \mathrm{C}$ eliminates classification as $B$. badius or B. stearothermophilus (Table 4). Furthermore, growth in the presence of $5 \% \mathrm{NaCl}$ and an inability to ferment glucose differentiate $B$. badius from the seven groups. Minimal growth temperatures of 30 to $45^{\circ} \mathrm{C}$, an acid $\mathrm{pH}$ in VogesProskauer broth, hydrolysis of starch, and an inability to degrade tyrosine are other characteristics that are exhibited by $B$. stearothermophilus but not by the members of the seven groups. Negative responses for alginate and starch hydrolysis, as well as for the fermentation of arabinose and xylose, indicate that the seven groups are phenotypically distinct from $B$. alginolyticus and $B$. chondroitinus.

DNA relatedness measurements and the results of phenotypic studies have demonstrated that the majority of strains studied have been erroneously classified as $B$. brevis. According to the results of such studies, 37 erroneously classified strains were members of seven genetically unrelated groups; these groups probably represent seven distinct species. Two of the groups represent species that have not been described previously, but some members of the remaining five groups have been classified as species other than $B$. brevis by previous researchers. It is interesting that the previous workers considered the phenotypic differences significant enough to give the organisms separate names. For example, strains in group 1 were received as "Bacillus hollandicus" Meyer and Stapp 1920, "Bacillus ventricosus" Bredemann and Heigener 1935, and "Bacillus agri" Laubach and Rice 1916; strains in group 3 were received as

TABLE 2. Levels of DNA relatedness between the seven group reference strains and selected Bacillus type strains

\begin{tabular}{|c|c|c|c|c|c|c|c|c|}
\hline \multirow[b]{2}{*}{ DNA from: } & \multirow{2}{*}{$\begin{array}{c}\mathrm{G}+\mathrm{C} \\
\text { content } \\
(\mathrm{mol} \%)\end{array}$} & \multicolumn{7}{|c|}{$\%$ Reassociation with DNA from strain ${ }^{a}$ : } \\
\hline & & $\begin{array}{c}\text { NRRL } \\
\text { NRS-1206 }\end{array}$ & $\begin{array}{l}\text { NRRL } \\
\text { B-1157 }\end{array}$ & $\begin{array}{c}\text { NRRL } \\
\text { NRS-135 }\end{array}$ & $\begin{array}{r}\text { NRRL } \\
\text { B-541 }\end{array}$ & $\begin{array}{l}\text { NRRL } \\
\text { NRS-818 }\end{array}$ & $\begin{array}{c}\text { NRRL } \\
\text { NRS-863 }\end{array}$ & $\begin{array}{c}\text { NRRL } \\
\text { NRS-376 }\end{array}$ \\
\hline B. badius NRRL NRS $-663^{T b}$ & 45 & 25 & 20 & 18 & 22 & 23 & 27 & 15 \\
\hline B. alginolyticus NRRL NRS-1347 ${ }^{\mathrm{T}}$ & 48 & 26 & 18 & 17 & 12 & 16 & 13 & 11 \\
\hline B. chondroitinus NRRL NRS $-1351^{\mathrm{T}}$ & 49 & 26 & 29 & 21 & 21 & 12 & 26 & 17 \\
\hline B. stearothermophilus NRRL B-1172 & 52 & 30 & 22 & 25 & 19 & 18 & 20 & 30 \\
\hline
\end{tabular}

\footnotetext{
${ }^{a}$ Reassociation values are averages of two determinations. The maximum variation observed was $6 \%$.
}

${ }^{b} \mathrm{~T}=$ type strain. 
TABLE 3. Phenotypic characteristics of the B. brevis DNA relatedness groups

\begin{tabular}{|c|c|c|c|c|c|c|c|c|c|}
\hline \multirow{2}{*}{ Characteristic } & \multicolumn{9}{|c|}{$\%$ of positive strains in ${ }^{a}:$} \\
\hline & $\begin{array}{l}\text { Group 1 } \\
(n=10)^{b}\end{array}$ & $\begin{array}{l}\text { Group 2 } \\
(n=4)\end{array}$ & $\begin{array}{c}\text { Group } 3 \\
(n=6)\end{array}$ & $\begin{array}{l}\text { Group } 4 \\
(n=3)\end{array}$ & $\begin{array}{l}\text { Group } 5 \\
(n=3)\end{array}$ & $\begin{array}{l}\text { Group } 6 \\
(n=3)\end{array}$ & $\begin{array}{l}\text { Group } 7 \\
(n=2)\end{array}$ & $\begin{array}{c}\text { Group } 8 \\
(n=6)\end{array}$ & $\begin{array}{l}\text { B. brevis } \\
(n=25)^{c}\end{array}$ \\
\hline Anaerobic growth & 0 & 0 & 0 & 0 & 0 & 0 & 0 & 0 & 0 \\
\hline Growth in the presence of $3 \% \mathrm{NaCl}$ & 0 & 0 & 0 & 0 & 0 & 0 & 0 & 0 & 0 \\
\hline Growth at pH 5.6 & 100 & 100 & 0 & 100 & 100 & 100 & 100 & 75 & 100 \\
\hline Growth at $50^{\circ} \mathrm{C}$ & 0 & 0 & 0 & 0 & 0 & 0 & 0 & 0 & 0 \\
\hline $\begin{array}{l}\text { Growth in the presence of } 0.001 \% \\
\text { lysozyme }\end{array}$ & 0 & 0 & 0 & 0 & 0 & 100 & 0 & 12 & 0 \\
\hline Casein hydrolysis & 100 & 0 & 0 & 100 & 0 & 100 & 0 & 43 & 100 \\
\hline Starch hydrolysis & 0 & 0 & 0 & 0 & 0 & 0 & 0 & 0 & 0 \\
\hline Nitrate reduced to nitrite & 0 & 0 & 33 & 100 & 0 & 100 & 0 & 57 & 100 \\
\hline Voges-Proskauer test ${ }^{d}$ & 0 & 0 & 0 & 0 & 0 & 0 & 0 & 0 & 0 \\
\hline Urease & 0 & 0 & 0 & 0 & 0 & 0 & 0 & 0 & 0 \\
\hline Egg yolk lecithinase & 0 & 0 & 0 & 0 & 0 & 0 & 0 & 0 & 0 \\
\hline $\mathrm{H}_{2} \mathrm{~S}$ production & 0 & 0 & 0 & 0 & 0 & 0 & 0 & 0 & 0 \\
\hline Catalase & 100 & 100 & 100 & 100 & 100 & 100 & 100 & 100 & 100 \\
\hline Oxidase & 0 & 0 & 0 & 0 & 0 & 0 & 0 & 0 & 100 \\
\hline Indole & 0 & 0 & 0 & 0 & 0 & 0 & 0 & 0 & 0 \\
\hline $\begin{array}{l}\mathrm{pH} \text { in Voges-Proskauer broth of } \\
>7.0\end{array}$ & 100 & 100 & 100 & 100 & 0 & 100 & 100 & 100 & 100 \\
\hline Utilization of citrate & 0 & 100 & 33 & 100 & 0 & 66 & 0 & 57 & 100 \\
\hline Utilization of propionate & 0 & 0 & 0 & 0 & 0 & 0 & 0 & 0 & 0 \\
\hline \multicolumn{10}{|l|}{ Fermentation of: } \\
\hline Arabinose & 0 & 0 & 0 & 0 & 0 & 0 & 0 & 0 & 0 \\
\hline Cellobiose & 50 & 0 & 100 & 100 & 100 & 0 & 0 & 57 & 100 \\
\hline Fructose & 100 & 100 & 0 & 0 & 100 & 100 & 100 & 43 & 100 \\
\hline Galactose & 0 & 0 & 0 & 0 & 0 & 0 & 0 & 0 & 100 \\
\hline Glucose & 100 & 100 & 100 & 100 & 100 & 100 & 100 & 100 & 100 \\
\hline Lactose & 0 & 0 & 0 & 0 & 0 & 0 & 0 & 0 & 0 \\
\hline Maltose & 100 & 100 & 100 & 100 & 100 & 100 & 100 & 86 & 100 \\
\hline Mannitol & 100 & 100 & 100 & 100 & 100 & 0 & 0 & 71 & 64 \\
\hline Mannose & 0 & 0 & 0 & 0 & 0 & 0 & 0 & 0 & 64 \\
\hline Melibiose & 0 & 0 & 0 & 0 & 0 & 0 & 0 & 0 & 0 \\
\hline Rhamnose & 0 & 100 & 100 & 0 & 0 & 0 & 0 & 0 & 0 \\
\hline Ribose & 100 & 100 & 100 & 67 & 100 & 0 & 100 & 100 & 100 \\
\hline Salicin & 0 & 0 & 0 & 0 & 0 & 0 & 0 & 0 & 0 \\
\hline Sorbitol & 0 & 0 & 0 & 0 & 0 & 0 & 0 & 0 & 0 \\
\hline Sucrose & 100 & 100 & 100 & 100 & 0 & 0 & 0 & 57 & 100 \\
\hline Trehalose & 100 & 100 & 100 & 100 & 0 & 0 & 0 & 57 & 100 \\
\hline Xylose & 0 & 0 & 0 & 0 & 0 & 0 & 0 & 0 & 0 \\
\hline
\end{tabular}

${ }^{a}$ The members of groups 1 through 7 are shown in Fig. 1. Group 8 contained the miscellaneous unrelated organisms.

${ }^{b} n$ is the number of strains in the group.

${ }^{c}$ Data from reference 10 .

${ }^{d}$ Test for acetylmethylcarbinol synthesis.

"Bacillus centrosporus" Ford 1916, "Bacillus pallidus" Bredemann and Heigener 1935, and "Bacillus ranus" Bredemann and Werner 1933; strains in group 4 were received as "Bacillus bellus" Bredemann and Heigener 1935; strains in group 6 were received as "Bacillus formosus" Bredemann and Heigener 1935 and "Bacillus rufescens" Bredemann and Stuhrk 1935; and strains in group 7 were received as " $B a$ cillus borstelensis" Bredemann and Stuhrk 1935. Because the genetic distinctiveness and phenotypic distinctiveness of groups 1 and 3 have been based on studies of adequate numbers of strains, these groups should be considered for proposal as the new species Bacillus agri and Bacillus centrosporus. In contrast to the description of Ford et al. (4), in this study no predilection by $B$. centrosporus to form spores centrally was observed. However, inasmuch as these are the oldest names used for members of these groups, the names $B$. agri and $B$. centrosporus are revived and used for the same taxa for which they were used originally, in accordance with Rules 27 and 28a of the International Code of Nomenclature of Bacteria (7). Strains NRRL NRS-1219 and NRRL NRS-664 are the type strains of $B$. agri and $B$. centrosporus, respectively. Descriptions of the species are given below.

Also present in this study were a number of strains which were not genetically related $B$. brevis sensu stricto or to the seven relatedness groups and displayed widely varied characteristics. Consequently, the phenotypic heterogeneity of $B$. brevis sensu lato was not due to the inherent variability of genetically related strains but was derived from the inclusion of a number of unrelated organisms in the taxon.

Description of Bacillus agri sp. nov., nom. rev. Bacillus agri (ag'ri. Gr. n. agrus, field; L. gen. n. agri, of a field).

Rods that are 0.5 to 1.0 by 2.0 to $5.0 \mu \mathrm{m}$. Gram positive. Motile. Ellipsoidal spores are produced in swollen sporangia.

Agar colonies are nonpigmented, translucent, thin, smooth, circular, entire, and about $2 \mathrm{~mm}$ in diameter.

Catalase positive. Oxidase is not produced.

Strictly aerobic. 
TABLE 4. Characteristics that differentiate groups 1 through 7 from B. badius, B. alginolyticus, B. chondroitinus, and $B$. stearothermophilus

\begin{tabular}{|c|c|c|c|c|c|c|c|c|c|c|c|}
\hline \multirow[b]{2}{*}{ Characteristic } & \multicolumn{7}{|c|}{ Group } & \multirow{2}{*}{$\begin{array}{c}B . \\
\text { badius }^{a}\end{array}$} & \multirow{2}{*}{$\begin{array}{l}\text { B. alginoly- } \\
\text { ticus }^{b}\end{array}$} & \multirow{2}{*}{$\begin{array}{l}\text { B. chondroi- } \\
\text { tinus }^{b}\end{array}$} & \multirow{2}{*}{$\begin{array}{l}\text { B. stearother- } \\
\text { mophilus }{ }^{a}\end{array}$} \\
\hline & $\begin{array}{c}\text { Group } \\
1\end{array}$ & $\underset{2}{\text { Group }}$ & $\underset{3}{\text { Group }}$ & $\underset{4}{\text { Group }}$ & $\begin{array}{c}\text { Group } \\
5\end{array}$ & $\underset{6}{\text { Group }}$ & $\underset{7}{\text { Group }}$ & & & & \\
\hline $\begin{array}{l}\mathrm{pH} \text { in Voges-Proskauer } \\
\text { broth }\end{array}$ & $>7.0$ & $>7.0$ & $>7.0$ & $>7.0$ & $<7.0$ & $>7.0$ & $>7.0$ & $>7.0$ & $>7.0$ & $>7.0$ & $<7.0$ \\
\hline Maximum growth temp $\left({ }^{\circ} \mathrm{C}\right)$ & $35-40$ & $35-40$ & $35-40$ & $35-40$ & $35-40$ & $35-40$ & $35-40$ & $45-50$ & $35-40$ & $35-40$ & $65-75$ \\
\hline Minimum growth temp $\left({ }^{\circ} \mathrm{C}\right)$ & $5-10$ & $5-10$ & $5-10$ & $5-10$ & $5-10$ & $5-10$ & $5-10$ & $10-15$ & $5-10$ & $5-10$ & $30-45$ \\
\hline $\begin{array}{l}\text { Growth in the presence of } \\
0.001 \% \text { lysozyme }\end{array}$ & $--^{c}$ & - & - & - & - & + & - & - & + & - & - \\
\hline Growth at pH 5.6 & + & + & - & + & + & + & + & - & + & + & - \\
\hline $\begin{array}{l}\text { Growth in the presence of } \\
5 \% \mathrm{NaCl}\end{array}$ & - & - & - & - & - & - & - & + & - & - & $\mathbf{v}$ \\
\hline \multicolumn{12}{|l|}{ Fermentation of: } \\
\hline Arabinose & - & - & - & - & - & - & - & - & + & + & $\mathbf{v}$ \\
\hline Glucose & + & + & + & + & + & + & + & - & + & + & + \\
\hline Mannitol & + & + & + & + & + & - & - & - & + & + & $\mathbf{v}$ \\
\hline Xylose & - & - & - & - & - & - & - & - & + & + & $\mathbf{v}$ \\
\hline Alginate hydrolysis & - & - & - & - & - & - & - & - & + & + & - \\
\hline Casein hydrolysis & + & - & - & - & - & + & - & + & - & - & $\mathrm{v}$ \\
\hline Starch hydrolysis & - & - & - & - & - & - & - & - & + & + & + \\
\hline Tyrosine hydrolysis & + & + & + & + & + & + & + & + & - & - & - \\
\hline Citrate utilization & - & - & $\mathbf{v}$ & + & - & $\mathbf{v}$ & - & + & - & - & + \\
\hline Nitrate reduction & - & - & $\mathbf{v}$ & + & - & + & - & - & - & - & $\mathbf{v}$ \\
\hline $\mathrm{G}+\mathrm{C}$ content $(\mathrm{mol} \%)$ & $52-55$ & $49-50$ & $49-51$ & $48-53$ & $48-53$ & $45-50$ & $49-53$ & $44-47$ & $47-49$ & $47-48$ & $44-52$ \\
\hline
\end{tabular}

${ }^{a}$ Physiological characteristics taken from reference $6 ; \mathrm{G}+\mathrm{C}$ values taken from reference 3 .

${ }^{b}$ Data taken from reference 9 .

${ }^{c}-$, negative reaction; + , positive reaction; $v$, variable reaction.

Acetylmethylcarbinol, hydrogen sulfide, and indole are not produced.

The $\mathrm{pH}$ in Voges-Proskauer broth (test for acetylmethylcarbinol production) is higher than 7.0.

Nitrate is not reduced to nitrite.

Starch, urea, and egg yolk lecithin are not hydrolyzed. Casein is hydrolyzed.

Citrate and propionate are not utilized.

Growth occurs at pH 5.6 or 5.7. Growth is inhibited by $3 \%$ $\mathrm{NaCl}, 0.001 \%$ lysozyme, and $50^{\circ} \mathrm{C}$.

The optimum growth temperature is $28^{\circ} \mathrm{C}$, the maximum growth temperature is $40^{\circ} \mathrm{C}$, and the minimum growth temperature is $10^{\circ} \mathrm{C}$.

Acid but no gas is produced from fructose, glucose, maltose, mannitol, ribose, sucrose, and trehalose. Variable acid production occurs with cellobiose. Arabinose, galactose, lactose, mannose, melibiose, rhamnose, salicin, sorbitol, and xylose are not fermented.

The DNA buoyant density is 1.7055 to $1.7084 \mathrm{~g} / \mathrm{cm}^{3}$; the $\mathrm{G}+\mathrm{C}$ content is 52 to $55 \mathrm{~mol} \%$.

Isolated from soil and clinical material.

The type strain, strain NRRL NRS-1219, has been deposited in the Agricultural Research Service Culture Collection at the National Center for Agricultural Utilization Research, Peoria, Ill.

Description of Bacillus centrosporus sp. nov., nom. rev. Bacillus centrosporus (cen.tro.spor'us. L. n. centrum, the center; M. L. n. spora, spore; M. L. adj. centrosporus, with a central spore).

Rods that are 0.5 to 1.0 by 2.0 to $6.0 \mu \mathrm{m}$. Gram positive. Motile. Elllipsoidal spores are produced in swollen sprangia.

Agar colonies are nonpigmented, translucent, thin, smooth, circular, entire, and 2 to $3 \mathrm{~mm}$ in diameter.

Catalase positive. Oxidase is not produced.

Strictly aerobic.
Acetylmethylcarbinol, hydrogen sulfide, and indole are not produced.

The $\mathrm{pH}$ in Voges-Proskauer broth (test for acetylmethylcarbinol production) is higher than 7.0.

Nitrate is reduced to nitrite by some strains.

Casein, egg yolk lecithin, starch, and urea are not hydrolyzed.

Citrate, but not propionate, is utilized by some strains.

Growth is inhibited at $\mathrm{pH} 5.6$ or 5.7 and by $3 \% \mathrm{NaCl}$, $0.001 \%$ lysozyme, and $50^{\circ} \mathrm{C}$.

The optimum growth temperature is $28^{\circ} \mathrm{C}$, the maximum growth temperature is $40^{\circ} \mathrm{C}$, and the minimum growth temperature is $10^{\circ} \mathrm{C}$.

Acid but no gas is produced from cellobiose, glucose, maltose, mannitol, rhamnose, ribose, sucrose, and trehalose. Arabinose, fructose, galactose, lactose, mannose, melibiose, salicin, sorbitol, and xylose are not fermented.

The DNA buoyant density is 1.7025 to $1.7045 \mathrm{~g} / \mathrm{cm}^{3}$; the $\mathrm{G}+\mathrm{C}$ content is 49 to $51 \mathrm{~mol} \%$.

The type strain, strain NRRL NRS-664, has been deposited in the Agricultural Research Service Culture Collection at the National Center for Agricultural Utilization Research, Peoria, Ill.

\section{ACKNOWLEDGMENT}

I thank J. Swezey for his invaluable technical assistance.

\section{REFERENCES}

1. De Ley, J., H. Cattoir, and A. Reynaerts. 1970. The quantitative measurement of DNA hybridization from renaturation rates. Eur. J. Biochem. 12:133-142.

2. Dubos, R. J., and R. D. Hotchkiss. 1941. The production of bactericidal substances by aerobic sporulating bacilli. J. Exp. Med. 73:629-640.

3. Fahmy, F., J. Flossdorf, and D. Claus. 1985. The DNA base 
composition of the type strains of the genus Bacillus. Syst. Appl. Microbiol. 6:60-65.

4. Ford, W. W., C. A. Laubach, and J. L. Rice. 1916. Studies on spore-bearing nonpathogenic bacteria. Part II. J. Bacteriol. 1:493-534.

5. Gause, G. F., and M. G. Brazhnikova. 1944. Gramicidin S. Origin and mode of action. Lancet ii:715-716.

6. Gordon, R. E., W. C. Haynes, and C. H. Pang. 1973. The genus Bacillus. U.S. Dep. Agric. Agric. Handb. 427:100-101.

7. Lapage, S. P., P. H. A. Sneath, E. F. Lessel, V. B. D. Skerman, H. P. R. Seeliger, and W. A. Clark (ed.). 1975. International code of nomenclature of bacteria. 1976 Revision. American Society for Microbiology, Washington, D.C.

8. Migula, W. 1900. System der Bakterien, vol. 2. Gustav Fisher, Jena, Germany.

9. Nakamura, L. K. 1987. Bacillus alginolyticus sp. nov. and Bacillus chondroitinus sp. nov., two alginate-degrading species. Int. J. Syst. Bacteriol. 37:284-286.

10. Nakamura, L. K. 1991. Bacillus brevis Migula 1900 taxonomy: reassociation and base composition of deoxyribonucleic acid. Int. J. Syst. Bacteriol. 41:510-515.

11. Nakamura, L. K., and J. Swezey. 1983. Taxonomy of Bacillus circulans Jordan 1890: base composition and reassociation of deoxyribonucleic acid. Int. J. Syst. Bacteriol. 33:46-52.

12. Priest, F. G., M. Goodfellow, and C. Todd. 1988. A numerical classification of the genus Bacillus. J. Gen. Microbiol. 134:18471882.

13. Schildkraut, C. L., J. Marmur, and P. Doty. 1962. Determination of the base composition of deoxyribonucleic acid from its buoyant density in CsCl. J. Mol. Biol. 4:430-443.

14. Singer, S., K. A. Doherty, and A. D. Stambaug. 1988. Abstr. Annu. Meet. Am. Soc. Microbiol. 1988, D34, p. 76.

15. Skerman, V. B. D., V. McGowan, and P. H. A. Sneath (ed.). 1980. Approved lists of bacterial names. Int. J. Syst. Bacteriol. 30:225-420.

16. Sneath, P. H. A., and R. R. Sokal. 1973. Numerical taxonomy. W. H. Freeman and Co., San Francisco.

17. Szybalski, W. 1968. Use of cesium sulfate for equilibrium density gradient centrifugation. Methods Enzymol. 12B:330 360 .

18. Udaka, S., N. Tsukagoshi, and H. Yamagata. 1989. Bacillus brevis, a host bacterium for efficient extracellular production of useful proteins. Biotechnol. Genet. Eng. Rev. 7:113-146. 